Тамара М. ЉУЈИЋ*

Универзитет у Београду

Филолошки факултет

(докторанд)
Оригинални научни рад

Примљен: 12. 11. 2018.

Прихваћен: 14. 02. 2019.

\title{
(НЕ)НАПИСАНА БИОГРАФИЈА ПЕТРА ІІ ПЕТРОВИЋА ЊЕГОША ПАВЛА ПОПОВИЋА
}

\begin{abstract}
Циљ рада јесте да се испитивањем методологије Павла Поповића у студијама посвећеним Петру II Петровићу Његошу пронађу препреке због којих целокупну биографију о Његошу овај књижевни историчар никада није написао. Анализирајући студије савременика, као и оних који су писали после Поповића на ову тему и са њим полемисали, трага се за разлогом због кога су Лажни цар Шћепан Мали и Луча микрокозма остали непротумачени од стране Поповића, који је недвомислено Његоша одредио као највећег српског песника. Преиспитивање значаја Горског вијенцяа у магистралном току српске културе дубоко је одредило Поповићев поглед на целокупно Његошево песничко дело.
\end{abstract}

Кључне речи: Павле Поповић, Петар II Петровић Његош, биографија, Горски вијенаи.

Сусрет читаоца и књижевног дела је интимни разговор индивидуалности личности и уникатности света књижевног дела. Сусрет књижевног дела и културе којој оно припада представља сусрет вредности, при чему је рецепција одређеног дела увек условљена политичко-историјским тренутком у коме се питање вредности поставља. Уколико се пође од идеје да је рецепција класика у једној култури увек двострука, да свако ново читање његовог дела може довести и до превредновања тог дела, очекивана је и појава две струје - оних који афирмишу његово место класика, и оних који се труде да то место оспоре. Самим покушајем да се место једног класика у култури оспори чини да он „преживљава као непроблематични идентитет управо услед оспоравања или прихватања" (Ломпар 2014: 229). Препознавши у Горском вијениу „добар и тачан етнографски приказ једне културне средине и истицање патриотске вредности дела", српска култура је већ у 19. веку одредила образац рецепције Његошевог књижевног дела - у додиру са колективним као врхунско дело препознаје се Горски вијенац, док остатак пишчевог опуса своју афирмацију може доживети само у сусрету са индивидуалним

\footnotetext{
*tamara.ljujic@gmail.com
} 
читаоцем. У дугој и богатој традицији његошологије у српској науци о књижевности место Павла Поповића је веома значајно јер је на самом почетку двадесетог века своје проучавање поставио „на основе ближе самом тексту дела" (Николић 2014: 427).

Одушевљење Павла Поповића животом и делом црногорског владике најбоље описују стихови Милорада Митровића „Јер колко си о Његошу писо/ И из хладног дизао га гроба/ Да смо тићи, па да су нам крила, / Па би главе изгубили оба! // О поноћи Владика се буди,/ Па у звучну он удара лиру:/, „Богом брате, Поповићу Павле,/ Остави ме једанпут на миру!” (Скерлић Ћоровић 2014: 216). Сведочење Поповићевог интимног пријатеља, а дато из перспективе жене која је Поповића дуго познавала, показује да његово интересовање није било кратког даха и да је било веома јако. Ово потврђује и чињеница да је Поповић у периоду од 25 година више пута писао и говорио о Његошевом животу и делу. Сматрајући га „највећим песником нашег народа" (Поповић 1999: 197), Поповић га у свом прегледу југословенске књижевности ${ }^{1}$ одређује као трећег великог песника југословенске књижевности, уз Прешерна и Мажуранића. Оцењујући њихова дела, Поповић се трудио да истакне подједнако сваког од тројице наведених, да увиди вредности сваког од њих, али приликом анализирања и поређења њихових дела, открива се став критичара да је „Горски вијенаи веће дело” (Исто), као и симпатије које је Поповић имао према Његошу.

Самеривши значај који сам аутор даје писцу о коме пише, не може се а не поставити питање зашто Павле Поповић никада није написао биографију Петра II Петровића Његоша. Под биографијом се овог пута подразумева студија целокупног дела једног писца, његовог јавног рада, као и подаци о његовом животу. Стога, најпрецизније би било овакву студију назвати свеобухватном монографијом о писцу, али пошто Поповић у својој студији о Видаковићу кроз етапе у животу писца прати и његово стваралаштво, трудећи се да уочи развоји пут како код личности, тако и код писца, термин биографија се може усвојити у најширем смислу. Да је Поповић био историчар књижевности који у свом раду тежи свеобухватној слици говоре његове студије о развоју српске и југословенске књижевности, али и књижевно-биографска студија посвећена Миловану Видаковићу. Слобода критичара

\footnotetext{
${ }^{1}$ Идеја о југословенској књижевности је код Поповића прихваћена као идеја коју треба заступати и неговати, али га је дубоко разумевање српске културе спречавало да заједништво јужнословенских књижевности проналази тамо где га није било: „Југословенска мисао, као у суштини свака права мисао о народности, творевина је новог доба” (Поповић 1999: 35) и „правог и потпуног јединства у њој (југословенској књижевности, додала Т. Љ.) нећемо, додуше, дуго наћи" (Исто: 108). Ипак, у жељи да нова књижевност добије своју заједничку прошлост, Поповић пише о „породици југословенских песника” (Исто: 70), у коју убраја Његоша, Мажуранића и Прешерна. Када је 1912. године написао предговор другом издању монографије Преглед српске књижевности, Поповић се осврнуо на став дела критике да је одабравши само српску, а не и хрватску књижевност за тему своје студије, испољио шовинизам. Бранећи се од напада, аутор је указао да се „српска књижевност може излагати без хрватске” (Поповић 1999: 7), мада се савременом проучаваоцу може учинити значајнија чињеница да је Поповић изазвао оштру критику одлуком да дубровачку књижевност укључи у студију посвећеној историји српске књижевност. Да аутор није занемарио и овај напад сведочи тврдња у истом предговору истакао „да се дубровачка књижевност може назвати српском бар онолико као и хрватском" (Исто).
} 
да тему свог истраживања изабере сам, а коју Поповић јесте имао, довела је до биографије Милована Видаковића, писца о коме су још савременици донели негативан суд, али не и до биографије писца кога је сам одредио као највећег српског песника. У првом поглављу монографије о Видаковићу Поповић осећа потребу да одбрани свој избор и наводи да „поред свих својих мана, он је увек једна крупна фигура у нашој књижевности" (Поповић 2000: 1) јер „он је почео роман у нас, он га је радио дуго и скоро једини, он га је и створио" (Исто: 2). Због значаја који је роман стекао у европској књижевности, Поповић је сматрао неопходним да осветли његов почетак код Срба, јер „Видаковића немају ни Хрвати, ни Словенци; немају га ни Бугари; имамо га само ми" (Поповић 2000: 2). Пишчев значај у историји српске књижевности навео је Поповића да напише „оглед који би обухватио наш предмет у целини: - анализу дела, компаративно истраживање, пишчев живот и личност, средину у којој се писац кретао” (Исто: 3). У овом одређењу потребних елемената за целокупну анализу и оцену пишчевог дела, али и представљање биографских елемената, уочава се „Поповићево поверење у позитивизам” (Николић 2014: 428), односно коришћење историјско-биографске научне методе. Узевши у обзир студије које је написао о Његошу и његовом делу, јасно је да би биографија црногорског владике морала наликовати, бар по својој структури, биографији коју је написао о Видаковићу.

Увођење студије о Миловану Видаковићу у разматрање проблема о непостојању Његошеве биографије у делу Павла Поповића отвара одређена питања. Елементи који су могли бити узрок непостојању Његошеве биографије су следећи: недостатак времена за рад на монографији, непостојање података потребних да монографија буде урађена, неприлагођеност методе проучавања књижевног дела, непостојање интересовања да се анализира Његошево целокупно дело.

Поповић је своју студију о Видаковићу објавио 1934. године у Београду. С обзиром на то да је преко четврт века радио на проучавању Његошевог дела, а да је студију о Горском вијениу објавио још 1900. године и да ју је допунио 1923. године, јасно је да је Поповић морао имати времена да напише Његошеву биографију ако је желео. У прилог тврдњи сведочи и упоређивање обима дела оба писца. Нетачно би било одредити комплексност тумачења књижевног дела према броју страна које је један писац написао, али свакако се не може занемарити да је Поповић пронашао време које би посветио тумачењу 1260 страна ${ }^{2}$ „Љубомира у Јелисијуму”, дела које описује као ,,један хаос, и колико садржи јединства то има да се захвали поглавито књиговесцу" (Поповић 2000: 109). Недостатак времена за посвећен рад на Његошевој биографији у светлу ових чињеница мора се одбацити као узрок за непостојање саме биографије.

Као препрека у писању монографије могао би бити и недостатак извора о песниковом животу, посебно када је реч о његовој младости: „приче о Њего-

\footnotetext{
${ }^{2}$ Према броју страна издања које је користио и које Поповић наводи у својој студији о Видаковићу.
} 
шевом детињству, најмање их има, и оне су, по правилу, настајале тенденциозно и ретроактивно у циљу попуњавања празнина у Његошевој приповедној биографији” (Златковић 2014: 245). Ипак, студије „Млади Његош” и „Петар II Петровић Његош у Бечу у годинама 1836-1837” откривају да је Поповић добро познавао изворе који су били доступни и од података које је имао могао је да обликује потребну причу. Трудећи се да у датим ситуацијама прикаже не само понашање владике, већ и да пружи основне информације о људима са којима се среће и опише локације које посећује, Поповић се приближава историографској прози, али, када описује осећања и размишљања свог јунака, он је на корак до књижевног дела: „задовољан је био и ведре душе” и ,а сањао је о том како ће себе образовати, усавршити, облагородити" (Поповић 2000a: 153). Открива се потреба критичара да писца кога проучава представи као личност: „Видаковић се после овога морао осетити врло утучен” (Поповић 2000: 189). У описивању осећања и духовних стања писца Поповић је дао себи много више слободе када је писао о Видаковићу, него када је писао о Његошу. Два су узрока Поповићевој слободи у описивању духовног расположења и размишљања Видаковића - аутобиографски спис који је Видаковић оставио и неформираност мишљења о пишчевој личности у јавној свести, што свакако није било у Његошовом случају. Када се чита Поповићева биографија посвећена Видаковићу, читалац пред собом нема сувопарну научну студију, оптерећену терминологијом, већ текст који смењује биографске делове и анализу „слабих” и ,јаких" места у одређеним делима. Неоптерећен идејом да пише о „великом писцу”, Поповић свој најбољи критичарски рад даје баш у студији посвећеној Видаковићу.

Проучаваоци Поповићеве методологије свој суд у највећој мери формирали су према студији посвећеној Његошевом Горском вијенщу. Најпрецизнији у анализи његовог метода је Ненад Николић када каже да су „Поповићеве интерпретације, дакле, пресудно условљене нормативном поетиком која тражи јединство предмета, композиције и радње" (Николић 2014: 435). У овим речима открива се немогућност Поповића да увиди специфичност композиције Горског вијенца, што је довело до његовог суда о коме се највише полемисало, а то је да је Његош „композицију упропастио” (Поповић 2000а: 48). Он не успева да аргументовано одбрани „високу оцену која анализи претходи” (Николић 2014: 436), јер „традиционална нормативна поетика не може објаснити јак естетски утисак” (Исто) књижевног дела, што доводи до тражења узора и увођења двоструких критеријума који би високу оцену оправдали. Тек је Јован Деретић 1969. године успео да у својој Композицији Горског вијенща оспори проблематичан суд проналазећи јединство у „тематском а не каузалном принципу” (Деретић 2017: 166). Као што је претходно наведено, Поповић је Горски вијенаи сматрао великим делом и желео да потврди место које је Његош имао у српској култури, али негативне примедбе морале су бити изречене упркос свести о величини анализираног дела: „Ми бисмо се, држим, исувише огрешили о високи појам који о критици имамо, кад бисмо и за тренутак покушали да ствар на силу улепшамо" (Поповић 2000a: 48). Ипак, док коментари поводом Видаковићевог дела данас могу 
изазвати и неверицу код савремених тумача због начина на који о њима, али и о писцу пише, који достиже кулминацију у изјави да писац губи сваки смисао текста да почиње и да „блеји”, негативни коментари поводом Горског вијенца много су умеренији. Поповићев суд поводом друга два Његошева спева је јасан: „Он написа Лучу микрокозма (1845), спев филозофских и узвишених мисли, која се заснива на једном епизоду Милтонова Изгубљена раја" (Поповић 1999: 66) и „Шћепана Малог (1851), недраматичну драму из црногорске историје" (Исто: 67). Да је Поповић написао монографију о Његошу, свакако да би морао један њен део посветити анализи и ова два владичина дела. Пошто је у студији о Горском вијениу имао проблем да одбрани вештину песника у обликовању „предмета великог, обимног националног значаја” (Поповић 2000а: 20), за Поповића би свакако био изазов да одбрани претпостављени положај Његоша као највећег српској песника приликом анализе оних дела која је он сматрао уметнички мање вредним. У анализи Горског вијенца Поповић се бавио светскоисторијским смислом, у потпуности занемаривши антрополошки и метафизички смисао дела. Његова неосетљивост за ове две равни Његошевог дела, свакако би довела до немогућности озбиљније анализе Луче микрокозма и Лажног цара Шћепана Малог.

Његошево место у српској култури дубоко је одређено његовом позицијом класика. Статус који заузима је „утемељујући и ограничавајући” (Ломпар 2014: 229), јер су херојски свет и косовски завет, препознати као темељ националног идентитета српског народа, одредили Горски вијенаи као класично дело српске књижевности. Управо је Његошева позиција у српској култури у 21. веку довела до напада на вредности у његовом делу, с тим да се „као предмет тумачења указује не укупно Његошево дело, него само један његов сегмент - Горски вијенаи”" (Булатовић 2018: 222-223), при чему се наведено дело „подвргава једном парцијалном и униформном виду тумачења (тј. прецизније речено - коментарисања) које има за циљ да оцрта линију непрекидног континуитета (и културног детерминизма) српске 'националистичке' идеологије и политичке праксе које се показују као геноцидне и освајачке” (Булатовић 2018: 223), а све да би се довело до „преиначавања српске културне и националне егзистенције у духу идеолошког конструкта српске кривице" (Ломпар 2018: 225). Противници вредности које је Његош у Горском вијениу одредио као вредности српског народа, посматране из ,актуелних геополитичких интересних тачки гледишта Запада" (Булатовић 2018: 228), извор су негативних и злочиначких потеза српског народа кроз историју, те да би српски народ престао да буде злочиначки, он мора престати да буде српски. Ипак, чак и када се инсистира на промени свести српског народа и одбацивања вредности херојског света који је Његош приказао у Горском вијениу, тумачи не увиђају да „управо тамо, где се утемељује српска културна парадигма, код Његоша, утемељује се и њена негација" (Ломпар 2014: $350)$ јер „нико није рекао о нашој хероици теже ствари од Његоша” (Исто). Ограничавање песника од стране једне културе види се на овом примеру јер чак ни они који желе да критикују Његошево дело у својој рецепцији немају 
Лажног изара Шћепана Малог, Његошево тестаментарно дело које је показало деградацију херојског друштва кроз секуларизовање његове метафизике.

Мајкл Селс у свом делу Изневерени мост: религија и геноцид у Босни истиче да ,до 19. века, Косовска битка није била централна тема српске епске поезије "” (Селс 1996: 37), већ истакнуто место највећег српског хероја заузима Марко Краљевић, „који је представљао контраст фигурама идентификованим са Косовском битком на начин који је створен од стране деветнаестовековних српских националиста ${ }^{4}$ (Исто). Жеља аутора да заоштри своје ставове јасна је у одабиру речи „контраст” јер би то значило да се Марко, за разлику од косовских јунака, није борио за српски народ. Начин борбе свакако је другачији јер ни услови нису исти - као турски вазал, он је могао да брани права својих сународника дарована од стране турског султана и са њима проживљава недаће које су их задесиле. Селс бира да јунаштво Марка Краљевића поистовети са његовом улогом неконфликтног посредника између два народа различитих вера. Аутор открива дубоко неразумевање начела херојског света српске народне епике и утицај тог света на поменуте „деветнаестовековне српске националисте". Током представе Цар Лазар Матије Бана 1887. године публика је бурно реаговала на појаву Марка Краљевића као негативног јунака. У овој драми Марко, желећи да се освети Лазару због одузимања круне коју је његов отац „крвљу својом исплатио” (Бан 1889: 123), и на коју сматра да има право, наводи Вука Бранковића на издају. Поставити јунака, који је вековима био симбол тихог отпора поробљеног народа, поред највећег издајника у народној традицији, Вука Бранковића, у време када се српска држава поново рађа, могло је резултирати само на начин на који се то и десило, односно, јаким незадовољством публике. ${ }^{5}$ Бан је Марка Краљевића описао као посредника између турског и српског света, при чему, вођен властитим интересима, он одлучује да се у овом сукобу приклони Турцима. Сам Поповић оштро је осудио начин на који је Видаковић у свом делу приказао Марка Краљевића, јер иако се „у Видаковићево време и раније о Марку није увек мислило како ми данас мислимо” (Видаковић 2000: 152), сматра да писац, који је Марка „комично и нескладно насликао”, није правично поступио према националном јунаку јер „за обичном памећу да је пошао па не би насликао оваквог Марка" (Исто). Романтичарски занос деветнаестог века, који је своје одушевљење пренео и на почетак двадесетог века, када је Поповић и писао своју студију посвећену Горском вијенцу, показао је да се измена националне легенде у очима публике не може оправдати ни унутрашњом логиком драмског текста, као што су то урадили Бан и Видаковић. Зато, када у 20. веку Јаша Продановић у предговору Лажног цзара Шћепана Малог пише да је Горски вијенаи, „познат и високој интелигенцији и једва писменом грађанину; мио је и страцу и младићу; „по три паса” одушевљавају се њиме у исто доба, његове стихове рецитују у парламентарним дебатама, цитирају у науч-

3 "Until the nineteenth century, the battle of Kosovo was not the central theme of Serbian epic".

${ }^{4}$ Stands in contrast to the polarizing figures identified with battle of Kosovo as it was configured by nineteenth-century Serbian nationalists.

5 Текст до данас није пронађен. 
ној полемици, у политичкој препирци, па чак и у личним сукобима” (Продановић 1902: 21), јасно је зашто Павле Поповић у свом раду пажњу усмерава на ово дело, а прелази преко потребе да се анализирају и друга два Његошева спева. Одредити једног песника као највећег песника културе, а не анализирати његово целокупно дело, не може бити оправдано. Не мора свако дело бити подједнако добро да би се песник одредио као велики, али потпуно занемарити део опуса пуно говори о ограничавању песниковог дела од стране критичара, али и културе. Свет Лажног ичара Шћепана Малог заиста би ставио тумача пред изазов, јер он није могао као Јаша Продановић протумачити спев као дело у коме је „Његош избацио из душе својих личности готово сва лична осећања, све егоистичне тежње, све индивидуалне слабости и ту празнину употпунио уношењем патриотског осећања". Након што је Видаковићу замерио обликовање Марковог лика супротно традицији, Поповић свакако не би могао занемарити уништавање матрице херојског света. Неосетљивост тумача за метафизичку раван онемогућила би тумача да продре у све слојеве Лажног ияара Шћепана Малог и Луче микрокозма. У студији коју је посветио Лучи микрокозма Поповић замера Његошу што у описивању „материјално описује величину простора уместо да је апстрактно формулише” (Поповић 2000а: 171), где прецизно анализира један детаљ из спева, али не покушава да анализу простора локализује у смисао целог дела. Питања теологије и метафизике нису представљале област Поповићевих интересовања, нити се њима ближе бавио у студијама које је писао. Ајлоз Шмаус пише анализу Луче микрокозма 1928. године, у којој се бави филозофском равни овог спева, али ни она не утиче дубље на Поповићево тумачење Његошевог дела, чија је рецепција дубоко одређена културном рецепцијом. Магистрала српске културе је као велико дело одредило само Горски вијенац. Зато и Јован Деретић у монографији Композищија Горског вијенца, која јесте обележила средину века у његошологији, иако другачије решава многа питања у традицији тумачења Горског вијениа, то не чини са друга два спева која посматра као „припрему” за ово дело. Само онај други део српске културе, који је Милован Ђилас у свом делу Легенда о Његошу осудио, а све са циљем „да се покаже како послије Николаја Велимировића идеализам није био кадар и не може бити кадар, да каже битно ново, не само о Његошу него ни о основним питањима филозофије, и да је све оно што је он чинио - а нарочито у вези с Његошем, а углавном и гносеолошким проблемима - било после охридско-љотићевског владике само млаћење празне сламе; а сам владика је - сем мистифицирања Његоша - скрознаскроз неоригиналан и плитак и без икаквог значаја” (Ђилас 1952: 106), могао је да у богатству индивидуалног духа својих тумача понуди отварање саме културе ка друга два спева. „Идеалисти” за које је Ђилас написао да су „данас стварно већ нијеми и могу да говоре само плиће и нејасније” (Ђилас 1952: 218) су били тумачи јаке индивидуалности и широког духовног богатства - владика Николај Велимировић, Исидора Секулић и Ајлоз Шмаус. Шмаус је био тај који је у својој студији о Његошевој Лучи микрокозма понудио нов начин читања Његошевог дела: „Паралеле које се могу извући из целокупног песништва владике Рада, с обзиром на његове метафизичке 
идеје, биле би веома захвалан предмет за расправљање. На тај начин могла би се створити теснија мисаона веза између појединих владичиних дела, што до данас није учињено, бар не на један систематски и исцрпан начин” (Шмаус 2000: 9). Требало је да прође нешто више од осамдесет година да би до оваквог једног тумачења заправо и дошло у делу Мила Ломпара, који је сагледавши метафизички слој Његошевих дела и истакнувши га у први план отворио нови хоризонт тумачења и на тај начин превазишао препреке које су његови претходници имали. Схватио је да је за тумачење овог песника потребно напустити некритички прихваћену идеју о биполарности Његошевог стваралаштва и да је потребно уврстити и његов последњи спев, јер се само на тај начин може доћи до целокупног тумачења.

Павле Поповић није написао монографију посвећену целокупном делу и животу Петра II Петровића Његоша зато што је био одређен нормативном поетиком, која је представљала препреку у тумачењу Горског вијенца. Кренувши од тврдње да је реч о „великом” делу, да би оправдао ову оцену, морао је да повлачи паралеле са античким трагедијама, не би ли могао да оправда оно што је он перципирао као „слабости” овог дела. Оваква методологија у проучавању књижевног дела није могла дати резултат у друга два Његошева спева, посебно не у Лажном изару Шћепану Малом, делу у коме се Његош открио као модеран песник. Други разлог јесте ограничење песниковог дела - српска култура ова два владичина дела перципирала је само на својим маргинама, у сурету индивидуалности духа и света уметничког дела. Након тумачења Павла Поповића, јавиле су се значајне студије и монографије које су кренуле путем који је он започео својом студијом о Горском вијениу, а које су се ослониле на сам књижевни текст, али и дубоко одушевљење Његошевим ликом. Његош се у српској култури и даље изнова чита и тумачи, а Поповићеве студије остају значајан почетак у проучавању песниковог дела.

\section{ЛИТЕРАТУРА}

Бан 1889: М. Бан, Дјела Матије Бана, књ. 3, Београд: Краљевско-српска државна штампарија.

Булатовић 2017: Б. Булатовић, Оклеветана књижевност: идеолошки аспекти у критичком сагледавању српске књижевности и културе крајем 20. и почетком 21. века, Нови Сад: Научно удружење за развој српских студија.

Детерић 2017: Ј. Деретић, Композиција Горског вијенца, Београд: Српска књижевна задруга.

Ђилас 1952: M. Đilas, Legenda o Njegošu, Beograd: Kultura.

Златковић 2014: Б. Златаковић, „Његош у анегдотама (Од детињства до 1834)”, у: Његош у своме времену и данас, Београд: Међународни славистички центар.

Ломпар 2012: М. Ломпар, Дух самопорицања: у сенцฺи туђинске власти, 3. Допуњено издање, Нови Сад: Orpheus. 
Ломпар 2018: М. Ломпар, Слобода и истина: белешке о промени свести, Београд: Catena mundi.

Николић 2014: Н. Николић, „Павле Поповић о Горском вијенцу: традиција, позитивизам и интерпретација", у: Његош у своме времену и данас 2, Београд: Међународни славистички центар.

Поповић 1999: П. Поповић, Југословенска књижевност, Београд: Завод за уџбенике и наставна средства.

Поповић 2000: П. Поповић, Милован Видаковић, Београд: Завод за уџбенике и наставна средства.

Поповић 2000а: П. Поповић, Његош, Београд: Завод за уџбенике и наставна средства.

Продановић 1902: Ј. Продановић, „Петар II Петровић Његош” у П. Петровић Његош, Лажни ияар Шћепан Мали, Београд: Српска књижевна задруга.

Селс 1996: M. Sells, The Bridge Betrayed: Religion and Genocide in Bosnia, Berkeley: University of California Press.

Скерлић Ћоровић 2014: Ј. Скерлић Ћоровић, Живот међу људима: мемоарски записи, Београд: Академска књига.

Шмаус 2000: А. Шмаус, Студије о Његошу, приредио Мирко Кривокапић, Подгорица: ЦИД.

\author{
Tamara Ljujić \\ (UN)WRITTEN BIOGRAPHY OF PETAR II PETROVIĆ NJEGOŠ \\ BY PAVLE POPOVIĆ
}

(Summary)

This paper analyzes methodology of Pavle Popović in studies dedicated to Peter II Petrović Njegoš and we are trying to find obstacles for which he never wrote the entire biography about Njegoš. Analyzing the studies of contemporaries, as well as those who wrote after Popović on this subject and polemisal with him, we are searching for the reason why Popović did not analyzed "Fake Car Šćepan Little" and "Luča mikrokozma". The re-examination of the importance of the "Mountain Wreath" in the mainstream of Serbian culture profoundly determined Popović's view of Njegoš's entire poetic work. 